\title{
REVIEW
}

\section{A Review of the Use of Tanning Beds as a Dermatological Treatment}

\author{
Kyle P. Radack • Michael E. Farhangian • \\ Kathryn L. Anderson · Steven R. Feldman
}

To view enhanced content go to www.dermtherapy-open.com Received: January 20, 2015 / Published online: March 4, 2015

(C) The Author(s) 2015. This article is published with open access at Springerlink.com

\begin{abstract}
Introduction: In-office phototherapy is an effective treatment for many dermatologic conditions, however, many patients are unable to adhere to the rigorous travel and time commitments sometimes needed. Tanning bed facilities are nearly ubiquitous in modern society and could represent a more convenient means to obtain ultraviolet (UV) exposure when office phototherapy is not feasible. The purpose of this study was to review available evidence on the use of tanning facilities as a treatment for dermatologic conditions.
\end{abstract}

Electronic supplementary material The online version of this article (doi:10.1007/s13555-015-0071-8) contains supplementary material, which is available to authorized users.

K. P. Radack · M. E. Farhangian ( $\square)$.

K. L. Anderson · S. R. Feldman

Department of Dermatology, Center for

Dermatology Research, Wake Forest School of

Medicine, Winston-Salem, NC, USA

e-mail: mfarhang@wakehealth.edu

S. R. Feldman

Department of Pathology, Wake Forest School of

Medicine, Winston-Salem, NC, USA

S. R. Feldman

Department of Public Health Sciences, Wake Forest

School of Medicine, Winston-Salem, NC, USA
Methods: PubMed was searched on February 2015 for "tanning beds" and "phototherapy", and with some dermatologic conditions sensitive to UV light, including "psoriasis", "mycosis fungoides", "acne", "atopic dermatitis" and "eczema". From there, further articles were found using the reference sections of the initial papers. A similar methodology was used with the Google Scholar search engine. Only articles in English and prospective studies were included in this review.

Results: We found studies validating the use of tanning facilities for psoriasis treatment. Use as a treatment option for atopic dermatitis, mycosis fungoides, acne, scleroderma, vitiligo, and pruritus, as well as other UV sensitive dermatoses, may also be beneficial. This study is limited by the lack of double-blind, placebocontrolled trials, long-term follow-up studies, and meta-analyses for tanning facility use in dermatologic phototherapy, and by the lack of standardization of both tanning facilities and exposure dosing.

Conclusion: Unsupervised sun exposure is a standard recommendation for some patients to obtain phototherapy. Selected use of commercial tanning beds in the treatment of 
dermatologic conditions may be another useful and effective treatment for those patients with an inability to access office-based or homebased phototherapy.

Keywords: Acne; Dermatitis; Eczema; Mycosis fungoides; Phototherapy; Pruritus; Psoriasis; Tanning beds

\section{INTRODUCTION}

Ultraviolet (UV) phototherapy is used for a myriad of dermatologic conditions such as psoriasis and mycosis fungoides (MF). UV phototherapy is most commonly administered in an office setting, with ideal treatment typically consisting of several sessions per week.

While phototherapy is effective for many conditions, the time and expense of this treatment can be a burden and an obstacle [1]. Many patients live over one hundred miles from a dermatologist or have other time and resource limitations that make in-office phototherapy inaccessible. Therefore, in-office phototherapy may not be a pragmatic treatment option for many patients who could potentially benefit from it.

Unsupervised sun exposure is a standard recommendation when in-office phototherapy is not feasible [2]. Commercial tanning facilities may offer another potential alternative means to access phototherapy, being both conveniently located and economically feasible. This can provide access to phototherapy to many patients who currently find treatment with in-office phototherapy to be cumbersome or impracticable. We examined available evidence for the use of commercial tanning facilities as a dermatologic treatment modality in diseases such as atopic dermatitis, acne, hand eczema, MF, vitiligo, and pruritus.

\section{METHODS}

Literature searches were done in PubMed in February 2015 combining therapy descriptor keywords, such as "tanning beds" and "phototherapy", with dermatologic conditions known or believed to be sensitive to UV light, including "psoriasis", "mycosis fungoides", "acne", and "atopic dermatitis"/"eczema". No inclusion or exclusion dates were defined. From there, further articles were found using the reference sections of the initial papers. A similar methodology was used with the Google Scholar search engine. Additional information was sought with targeted searches in both PubMed and Google Scholar. In conditions that did not have studies using commercial tanning beds, we investigated the efficacy of UV radiation overlapping with the emission spectrum of tanning beds. Only articles in English and prospective studies were included in this review. This article is based on previously conducted studies and does not involve any new studies of human or animal subjects performed by any of the authors.

\section{RESULTS}

\section{Characteristics of Indoor Tanning Light}

The light used during indoor tanning is poorly defined. The US Food and Drug Administration does not specify limits on the power of UV light emissions, instead defining "irradiance ratio limits", where the ratio of irradiance between wavelengths of 200 and $260 \mathrm{~nm}$ to the irradiance between wavelengths 260 and $320 \mathrm{~nm}$ should not exceed 0.003 at any distance and direction from the source [3]. While in the US there are state and federal regulations, according to a study performed in 
North Carolina, the extent to which commercial tanning facilities comply is poor, with only 1 out of 32 commercial tanning establishments within complete compliance of state and federal guidelines [4].

The wavelengths of UVA and UVB irradiation from tanning beds are highly variable; however, tanning beds as a whole tend to emit primarily UVA irradiation. Rates of UVB emissions range from $0.5 \%$ to $5.0 \%$ in North Carolina tanning beds [4]. Another study of North Carolina tanning beds found a wide range of UVA irradiance, $17.7-674.0 \mathrm{~W} / \mathrm{m}^{2}$ and a UVB range of $0.12-0.82 \mathrm{~W} / \mathrm{m}^{2}(2.11-14.00$ minimal erythemal dose/h) [5].

Tanning beds analyzed in the UK between 2004 and 2005 showed tremendous variability in spectral distribution of UV output, resulting in the average erythemal irradiance ranging from $0.02-0.93 \mathrm{~W} / \mathrm{m}^{2}$, with an average of $0.41 \mathrm{~W} / \mathrm{m}^{2}$ [6]. In a study conducted in 2008, 78 indoor tanning facilities from 6 regions throughout Norway were characterized [7]. The average UVB irradiance was $0.194 \mathrm{~W} / \mathrm{m}^{2}$ erythema-weighted dose (range 0.059-0.489 $\mathrm{W} / \mathrm{m}^{2}$ ), and the average UVA irradiance was $0.156 \mathrm{~W} / \mathrm{m}^{2}$ erythema-weighted dose (range $0.079-0.568 \mathrm{~W} / \mathrm{m}^{2}$ ). Norway regulates indoor tanning facilities, with both short-wave and long-wave UV irradiance limits set at $0.15 \mathrm{~W} /$ $\mathrm{m}^{2}$. Only $23.3 \%$ of tanning facilities were in compliance with maximal irradiances for both UVA and UVB spectra. Ninety-six percent of tanning bed devices were approved models, but only $74 \%$ of lamps in these tanning beds were an approved type. The maximum erythemaweighted UV irradiance varied by up to a factor of 2 for the same tanning bed devices in different facilities, due to the difference in lamps used. Additionally, within each facility, irradiance measures varied by up to a factor of two, due to the different tanning bed devices
[7]. The variety of tanning bed devices and lack of standardization of lamps within these devices present a therapeutic hurdle to recommending their use as a treatment for skin disease.

\section{Efficacy of Tanning Beds}

While different tanning beds emit variable amounts of UVB and UVA (varying in both the absolute flux and the ratio of UVB to UVA), there is extensive in vitro evidence that both UVA and UVB have anti-inflammatory effects (Tables 1, 2).

\section{Risks of Tanning}

As with any UV light-based therapies, there are potential risks of using tanning beds as treatment (Table 3). There is a link between artificial UV light exposure and an increased risk of developing skin cancer. In 2006, a metaanalysis showed an increased risk of developing melanoma, squamous cell carcinoma (SCC), and basal cell carcinoma (BCC) in patients who have ever used a tanning bed compared with those who have never tanned with artificial UV light [8]. A particularly large increase in melanoma risk was found when comparing those who ever tanned before age 35 years to those who had never used an indoor tanning device. A subsequent study found a dose/response relationship between artificial UV light exposure and increasing risk of melanoma, with those having tanned 10 times or fewer having only a $34 \%$ increased risk of developing a melanoma, compared to $272 \%$ in those patients who have used indoor tanning beds over 100 times [9]. In a more recent study, an association was found between age of first tanning bed exposure and increased risk of melanoma in patients with more than 10 tanning bed exposures [10]. A large 
Table 1 Summary of the known anti-inflammatory mechanisms of UV light

\begin{tabular}{ll}
\hline Type of & Anti-inflammatory mechanisms \\
UV & \\
\hline UVA & Induces expression of HO-1, which catalyzes the degradation of heme to biliverdin and bilirubin, themselves \\
& potent antioxidants, and to carbon monoxide, which suppresses proinflammatory cytokines. HO- 1 \\
& activation may play a immunoprotective role in humans from increased IFN- $\gamma$ as well. Langerhans cell \\
& counts are decreased in human epidermis after 4 weeks of UVA tanning bed exposure [60] \\
& Blood $\mathrm{CD}_{3}{ }^{+}$and $\mathrm{CD}_{4}{ }^{+}$counts are reduced in patients after exposure to UVA dominant tanning bed \\
& treatments $[61]$
\end{tabular}

UVB UVB depletes of LC, the major antigen-presenting cell of the skin, through migration of damaged LCs to regional lymph nodes and through direct apoptosis. UVB exposed LCs preferential present antigens to Th2 and do not stimulate Th1. UVB irradiation induces T-suppressor and immunotolerant macrophages in the epidermis [62]

Suppression of ICAM-1 expression by keratinocytes associated with a significant increase in intracellular thymine dimers in vivo with restoration of ICAM-1 expression via topical DNA repair enzyme [63]

Both CGRP is released from cutaneous nerves after xposure to UVR, increasing cAMP levels in T cells, inhibiting $T$ cell proliferation and inhibiting the production of IL- 2 and expression of TNF- $\alpha$, TNF- $\beta$ and IFN- $\gamma$. CGRP also causes mast cells to degranulate and release TNF- $\alpha$, which can interfere with APC's ability to initiate the inflammatory cascade [64]

The UV-induced mast cell degranulation releases the anti-inflammatory cytokine IL-10. UV irradiation damages keratinocyte DNA, activating p53 and subsequently increasing the transcription of POMC, which itself induces further production of IL-10 [65]

Stimulates HDMEC to produce $\alpha$-melanocyte-stimulating hormone, inhibiting expression of the adhesion molecules VCAM-1 and E-selectin, inhibiting the extravasation of leukocytes during inflammation [64]

PUVA Induces cell death by inducing DNA damage, initiating a delayed apoptotic cascade [66]

$A P C$ antigen-presenting cell, $C G R P$ calcitonin gene-related peptide, HDMEC human dermal microvascular endothelial cells, HO- 1 heme oxygenase, ICAM- 1 intracellular adhesion molecule 1, IFN Interferon, $I L$ interleukin, $L C$ langerhans cells, $P O M C$ proopiomelanocortin, $P U V A$ psoralen ultraviolet A, Th1 type $1 \mathrm{~T}$ cells, Th2 Type $2 \mathrm{~T}$ cells, TNF tumor necrosis factor, $U V$ ultraviolet, $U V R$ ultraviolet radiation, $V C A M-1$ vascular cell adhesion molecule 1

prospective study found no association between age range of most frequent tanning bed use and risk of melanoma or SCC, but did find an even greater risk of BCC in women who visited tanning beds most frequently during their high school and college years compared to those who visited most frequently during age 25-35 years, both of which were greater than the risk in women who had never used a tanning bed [11]. This was further supported by findings that a dose/response relationship can be found between the risk of developing a BCC and increasing numbers of tanning sessions, hours spent indoor tanning, years spent indoor tanning, number of burns at the biopsy site, and number of burns associated with indoor tanning [12]. This study also found a strong relationship with artificial UV light exposure and truncal BCCs, as compared to the head and neck, indicating a possible increases susceptibility of bodily areas that receive less incidental solar irradiation [12]. Furthermore, 
Table 2 Summary of evidence supporting commercial tanning beds or UV light in the treatment of selected dermatologic conditions graded on the basis of level of evidence by using the Scottish Intercollegiate Guidelines Networks grading recommendations

\begin{tabular}{|c|c|c|c|}
\hline $\begin{array}{l}\text { Dermatologic } \\
\text { condition }\end{array}$ & Description of evidence & $\begin{array}{l}\text { Level of evidence } \\
\text { supporting UV } \\
\text { light }\end{array}$ & $\begin{array}{l}\text { Level of evidence } \\
\text { supporting commercial } \\
\text { tanning beds }\end{array}$ \\
\hline \multirow[t]{4}{*}{ Psoriasis } & $\begin{array}{l}\text { Within-patient control supports both high and lower } \\
\text { percentage UVB output tanning bed light }[18]\end{array}$ & & $\mathrm{Ib}$ \\
\hline & $\begin{array}{l}\text { Clinical trial demonstrates more improvement in PASI } \\
\text { with increased UV light exposure [19] }\end{array}$ & & $\mathrm{IIb}$ \\
\hline & $\begin{array}{l}\text { Increased reduction in PASI score of unilateral side of } \\
\text { patients treated with UVA dominant light vs. the } \\
\text { contralateral side treated with dominantly visible light } \\
\text { [22] }\end{array}$ & & IIa \\
\hline & $\begin{array}{l}\text { Randomized controlled trial noted a } 74 \% \text { reduction in } \\
\text { PASI } 75 \text { scores in patients using home UVB vs. } 70 \% \\
\text { reduction in outpatient UVB [25] }\end{array}$ & $\mathrm{IIb}$ & \\
\hline Acne & $\begin{array}{l}\text { Experimental trial for blue light }[67] \text { and red-blue light } \\
\text { [68], and photodynamic therapy }[27,28] \text { but no } \\
\text { direct evidence for ultraviolet light }\end{array}$ & & \\
\hline $\begin{array}{l}\text { Atopic } \\
\text { dermatitis }\end{array}$ & $\begin{array}{l}\text { NB-UVA1, medium-dose UVA1, NB-UVB, and } \\
\text { combination UVA/UVB irradiation have } \\
\text { demonstrated efficacy }[21,30-32,35]\end{array}$ & $\begin{array}{l}\text { IIa } \\
\text { IIb } \\
\text { IIb } \\
\text { IIb } \\
\text { IIa } \\
\text { IIa }\end{array}$ & \\
\hline Hand eczema & $\begin{array}{l}\text { Oral methoxsalen UVA treatments three times per } \\
\text { week at home with a portable facial tanning unit was } \\
\text { found to be as effective as inpatient, biweekly } \\
\text { trioxsalen bath UVA treatments [38] }\end{array}$ & $\mathrm{Ib}$ & \\
\hline \multirow[t]{3}{*}{ CTLC } & $\begin{array}{l}\text { 4/4 Stage I/II CTCL plaques cleared with } 120 \mathrm{~J} / \mathrm{cm}^{2} \\
\text { max dose UVA1 and } 3 / 4 \text { cleared with } 80 \mathrm{~J} / \mathrm{cm}^{2} \max \\
\text { dose [40] }\end{array}$ & $\begin{array}{l}\text { IIb } \\
\text { IIc }\end{array}$ & \\
\hline & $\begin{array}{l}\text { Treatment NB-UVB ranging from led to complete } \\
\text { remission in } 76.4 \% \text { of patients [39] }\end{array}$ & & \\
\hline & $\begin{array}{l}\text { NB-UVB found to be effective in } 6 / 8 \text { patients with } \\
\text { Stage I CTCL [69] }\end{array}$ & IIb & \\
\hline
\end{tabular}


Table 2 continued

\begin{tabular}{|c|c|c|c|}
\hline $\begin{array}{l}\text { Dermatologic } \\
\text { condition }\end{array}$ & Description of evidence & $\begin{array}{l}\text { Level of evidence } \\
\text { supporting UV } \\
\text { light }\end{array}$ & $\begin{array}{l}\text { Level of evidence } \\
\text { supporting commercial } \\
\text { tanning beds }\end{array}$ \\
\hline Vitiligo & $\begin{array}{l}\text { PUVA [70], broadband and NB-UVB }[42-45,70,71] \text {, } \\
\text { and excimer laser [72] with/without adjuvant } \\
\text { therapies, employed in the treatment of vitiligo [41] }\end{array}$ & $\begin{array}{l}\mathrm{Ib} \\
\mathrm{Ib} \\
\mathrm{Ib} \\
\mathrm{IIb} \\
\mathrm{IIc} \\
\mathrm{IIc} \\
\mathrm{IIb}\end{array}$ & \\
\hline $\begin{array}{l}\text { Uremic } \\
\text { pruritus }\end{array}$ & $\begin{array}{l}\text { UVB light effective in } 80-90 \% \text { of patients with uremic } \\
\text { pruritus [54] and NB-UVB was also effective in } \\
\text { decreasing symptoms of pruritus in patients on dialysis } \\
\text { [51] }\end{array}$ & $\begin{array}{l}\text { IIa } \\
\text { IIb }\end{array}$ & \\
\hline
\end{tabular}

CTLC cutaneous T cell lymphoma, NB narrow band, PASI Psoriasis Area Severity Index, PUVA psoralen ultraviolet A, $U V$ ultraviolet

Table 3 Risks and side effects associated with excess ultraviolet light exposure [73]

\begin{tabular}{ll}
\hline Erythema & Epidermal hyperplasia \\
Pruritus & Dermal edema \\
Polymorphic light eruption & Perivascular inflammation \\
Immune system modulation & Tanning \\
Cutaneous malignancy & Photoaging \\
\hline
\end{tabular}

the World Health Organization characterizes tanning beds as carcinogenic to humans, therefore, caution should be exercised in recommending tanning beds for treatment, especially in those who are at risk for developing melanoma or other skin cancers [13]. While there is strong evidence supporting association of tanning bed use and the increased risk of skin cancer, some of this association may not be causal in nature.

\section{Tanning and Conditions Treated by Phototherapy}

\section{Psoriasis}

Assessing the evidence for commercial tanning facilities as a treatment for psoriasis is important as indoor tanning is already commonly used by people as a psoriasis treatment, perhaps the most frequently used form of phototherapy for psoriasis. One center reported that more than $50 \%$ of patients presenting to their clinic had tried or were currently treating their psoriasis with commercial tanning sessions [14]. Another survey found that $36 \%$ of patients reported having tried commercial tanning beds as a psoriasis treatment [15].

There may be concern that tanning beds that emit primarily UVA would not be effective for the treatment of psoriasis. While one study 
found that UVA doses up to $30 \mathrm{~J} / \mathrm{cm}^{2}$ were ineffective for psoriasis, Parrish [16] found that psoriatic plaques are responsive to erythemogenic doses of either UVA or UVB light $[16,17]$. The ability of tanning beds to treat psoriasis was compared on the basis of their UVB output, one with a UVB output of $4.6 \%$ was compared to another with a lower UVB output $(0.7 \%)$ in a within-patient comparison technique [18]. There were marked and equivalent improvements in Psoriasis Area Severity Index (PASI) scores from baseline in patients treated unilaterally with either lamp with 12 exposures to an equal erythemal dose over a 4-week period. While exposure to either UVA or UVB light can induce clearance of psoriatic plaques, UVA requires more energy (time $\times$ power) to reach erythemogenic dosing [16].

The ability of a specific tanning bed using the Bellarium S lamp (a commonly used tanning bulb) to clear psoriatic plaques was tested in a clinical trial [19]. Twenty patients with psoriasis vulgaris were treated with three to five tanning bed sessions per week for a 6-week period. Sixteen patients had improvement in their disease as measured by PASI and 17 patients as measured by the self-administered PASI (SAPASI). The average reduction in the PASI and SAPASI was $35.4 \%$ and $36.2 \%$, respectively, for all enrolled patients and $39.4 \%$ and $52.3 \%$, respectively, in those completing the 6-week study. A clear dose response was observed, with greater cumulative UV exposure associated with greater disease improvement. The magnitude of PASI reduction was modest compared to recent studies of biologics, but the authors commented that the improvement was comparable to PASI reductions reported in patients treated with betamethasone valerate, calcipotriol, dithranol, and etretinate [20, 21].
Short-term side effects were minimal, including mild phototoxic reactions in seven patients and itching in three patients [15]. Long-term risks, however, were not assessed. Overall, this study demonstrated the efficacy and feasibility of using commercial tanning beds in the treatment of psoriasis, but as the tanning bed treatments were administered in a wellmonitored medical setting, the findings may not fully extrapolate to tanning in the community setting.

A study assessing the effectiveness of a UVA light-dominant commercial tanning unit compared to visible light using each patient as their own control demonstrated a slight, but significant improvement in the PASI score, with the difference coming from an improvement in the erythema component of the PASI score [22].

One of the most effective treatments for psoriasis is the combination of phototherapy and oral retinoids [23]. Acitretin and tanning bed UV exposure combination therapy has been studied and is more effective than tanning alone, with $83 \%$ of patients achieving clearance or near clearance in a retrospective review, and PASI scores demonstrating an average reduction of $79 \%$ from baseline in a prospective open-label trial of 17 patients [24]. Not only did many patients clear or experience near clearing of the psoriasis, but in both the retrospective review and prospective trial, several patients were able to remain clear after stopping acitretin and only using two maintenance tanning bed light treatments per week. This illustrates the potential for tanning bed treatments as the only maintenance therapy for patients who are currently clear of their psoriasis [24].

Home UVB therapy is also a convenient option for patients with psoriasis, although not all patients have access to it. One randomized, controlled study comparing 
home UVB to outpatient administered UVB treatment demonstrated similar efficacy to that of outpatient UVB therapy [25]. In this study, median PASI scores decreased for patients receiving home phototherapy 74\%, respectively, compared to a $70 \%$ decrease in the outpatient phototherapy group.

\section{Acne}

Various light source therapies are either currently used or under investigation for the treatment of acne vulgaris, mainly pulsed dye laser or photodynamic therapy [26-28]. While the evidence for the use of tanning beds to treat acne is limited, in a study of Swedish tanning bed users, $34 \%$ believed that sunbathing in natural light improved acne versus only $11 \%$ of non-users, which suggests a potential use of tanning beds as a possible adjuvant treatment for acne [29]. However, we did not identify any clinical trial supporting the use of tanning bed UV light in the treatment of acne vulgaris.

\section{Atopic Dermatitis}

The prevalence of therapeutic use of tanning beds in patients with atopic dermatitis has been reported to be $66 \%$ [29]. This is not unexpected as narrow band (NB) UVA1, medium-dose UVA1, and combination UVA/UVB irradiation have been successfully employed as treatments for atopic dermatitis [30-32].

Daily exposure to high-dose UVA1 $(130 \mathrm{~J} /$ $\mathrm{cm}^{2}$ ) resulted in significant improvement of study subjects' atopic dermatitis [21]. UVA1 $\left(60 \mathrm{~J} / \mathrm{cm}^{2}\right)$ is equally effective compared to topical tacrolimus in treating atopic dermatitis [33]. UVA/UVB treatment was also effective at reducing clinical score [34]. NB-UVB as monotherapy is also effective in treating atopic dermatitis [35]. To our knowledge, no studies have been done investigating the use of tanning beds in atopic dermatitis, however, the range of UV light sources demonstrated to be effective in the treatment of atopic dermatitis suggests that the use of tanning beds as a treatment for atopic dermatitis may be efficacious.

\section{Hand Eczema}

Psoralen UVA (PUVA) is highly effective in the treatment of hand eczema $[36,37]$. In an openlabel randomized controlled trial comparing two established protocols, oral methoxsalen UVA treatments three times per week at home with a portable facial tanning unit were found to be as effective as inpatient, biweekly trioxsalen bath UVA treatments [38]. A $9 \mathrm{~mW} /$ $\mathrm{cm}^{2}\left(90 \mathrm{~W} / \mathrm{m}^{2}\right)$ UVA facial tanning unit was used; the power output of this device is far below the average of $192.1 \mathrm{~W} / \mathrm{m}^{2}$ found in the North Carolina tanning bed study. Due to commercial tanning beds having primarily UVA irradiation, use of tanning beds with psoralen may have a place in the out of office treatment of chronic hand eczema, however, care must be taken because of the risks of severe burns. Concurrent use of tanning beds and psoralen may be potentially used in hand eczema due to the low body surface area involved, as patients would only need to expose their hands to the tanning bed radiation. The application of psoralen to extensive areas or systemic psoralen should not be used with tanning beds, as the risks of burns may be life threatening in these patients.

\section{Cutaneous T Cell Lymphoma}

Various phototherapeutic modalities are currently used for MF. Treatment with NBUVB is effective for MF, leading to complete remission in the majority of patients [39]. The efficacy of five times weekly UVA1 phototherapy for the treatment of MF was also investigated [40]. After 3 initial treatment 
sessions with standardized doses of 10, 20, and $40 \mathrm{~J} / \mathrm{cm}^{2}$, symptoms were used to determine future dosing, with all 4 patients clearing with maximum doses of $120 \mathrm{~J} / \mathrm{cm}^{2}$ UVA1 and 3 out of 4 clearing with maximum doses of $80 \mathrm{~J} / \mathrm{cm}^{2}$. With minimal erythemal dosing of UVA light noted to be $10-100 \mathrm{~J} / \mathrm{cm}^{2}$ [16] commercial tanning beds could be used to deliver therapeutic doses of UVA light in the treatment of cutaneous $\mathrm{T}$ cell lymphoma, though we found no reported cases of this therapeutic approach.

\section{Vitiligo}

Many UV-based therapies are employed when treating vitiligo, including PUVA, NB-UVB (both in office and home units) and excimer laser, along with adjuvant treatments such as topical calcineurin inhibitors and topical corticosteroids [41-44]. One study found that broadband UVB phototherapy was superior to NB-UVB in treating vitiligo, which suggests that tanning beds would also be effective [45]. Sun exposure induces repigmentation of vitiligo lesions during the summer in many patients [46]. While there is a possibility of using commercial tanning beds to deliver therapeutic doses of UV light to patients with vitiligo, we did not find clinical trials assessing this potential use.

\section{Pruritus}

The pathophysiology of itch is still being elucidated, and the mechanism by which UV light reduces pruritus is not well defined. Given the relative lack of penetration of UVB through the epidermis, the effect of UVB is thought to be through its action on epidermal keratinocytes and Langerhans cells. The effects of UVA light are generally believed to be dermal in origin, affecting lymphocytes, mast cells, and fibroblasts [47]. Dermal Schwann cells and perineural cells degenerate after exposure to UVA light as well [48].

UVB light has been successfully employed in the treatment of uremic pruritus for decades. Early studies demonstrated the efficacy of broadband UVB, with 9 out of 10 patients experiencing a significant reduction in pruritus [49]. NB-UVB is also effective [50, 51]. There are several theories on the mechanism of UVB light in the treatment of uremic pruritus, including UVB-induced reduction in skin phosphorus, leading to decreased microprecipitation of divalent cations with phosphorous in the skin and UVB-induced mast cell apoptosis [52, 53]. There may be a systemic effect of UV on uremic itch, as patients treated unilaterally with UVB light report a reduction in pruritus on both sides of their body [54].

HIV pruritus can be treated with either UVB or PUVA $[55,56]$. And while in vitro and animal studies on the safety of UV light therapy raise concerns about induction of viral replication, these safety concerns have not shown up in vivo, and reviews of the literature have endorsed UV light therapy as safe in this setting [57, 58]. However, we found no data on the potential use of commercial tanning beds in the treatment of HIV-associated pruritus.

\section{DISCUSSION}

Many skin conditions are responsive to office phototherapy, however, office phototherapy can be expensive and inconvenient. Home UVB therapy is a potential alternative. When phototherapy is desired and office and home UVB treatments are not feasible, indoor tanning may be of benefit. There are certainly limitations to this approach-imprecise outputs of the lamps and beds, imprecise spectral targeting of commercial tanning beds, 
administration by the patient or non-medical staff, acute and long-term side effects-but there are limitations to all treatment options. Due to the significant risks of tanning beds and the potential variability in dosing, practitioners should exercise their clinical judgment in recommending it to their patients. While some patients may benefit, others may have significant risk factors, such as a predisposition to skin cancer, that would need to be taken into account (along with the risks of other treatments and the risk of suffering with no treatment) when recommending treatment options.

A significant concern for use of commercial tanning facilities in phototherapy is their considerable variability in emission make up and dosing. Variability in exposure can be reduced by selecting a single bed, with additional caution/dose reduction when bulbs are changed; doing so may provide more predictable dosimetry than is obtainable with sun exposure. For psoriasis treatment, 3-5 sessions per week for 6 weeks with $4.6 \%$ UVB tanning lamps was effective (Table 4) [19]. The length of the sessions was based upon selfreported skin type and the manufacturer's suggestions for the particular bulb used in that study. For patients on an oral retinoid, a starting dose of 2-3 min with $1 \mathrm{~min}$ incremental increases (30 min maximum), 5-7 times a week was safe in a single study that used a 4.7\% UVB output commercial tanning unit
(Table 5) [24]. Because of the variability between different tanning beds, these data can give only a limited reference point for dosing; starting with a low dose and increasing slowly as tolerated would be prudent.

Given the variability demonstrated in the UV output of indoor tanning devices, we recommend some practical safety tips (Table 5). Patients should keep treatment time the same if they have asymptomatic pinkness or erythema of the skin and should be aware side effects such as pain and/or blisters. Patients with lighter skin types should exercise more care as they are more susceptible to burns from tanning compared to darker skinned individuals. After about six times per week for 1 month, reassess for response to treatment. This approach maximizes safety and allows for increasing doses as tolerated.

This study is limited by the lack of doubleblind, placebo-controlled trials, long-term follow-up studies and meta-analyses for tanning facility use in dermatologic phototherapy, and by the lack of standardization of both tanning facilities and exposure dosing. Furthermore, much of what is extrapolated for the efficacy of tanning beds is through methods which emit UV therapy that overlaps with the UV emissions of tanning beds.

Commercial tanning beds have been successfully used as a treatment modality for patients with psoriasis, and show promise for the treatment of many other dermatoses

Table 4 Fleischer et al. [19] exposure schedule for the use of tanning beds for psoriasis treatment

\begin{tabular}{llllllll}
\hline Skin type & \multicolumn{2}{l}{ Exposure, min } & & Sessions per week \\
\cline { 2 - 8 } & Week 1 & Week 2 & Week 3 & Week 4 & Week 5 & Week 6 & \\
\hline I & 2 & 4 & 10 & 15 & 20 & 25 & $3-5$ \\
II & 3 & 7 & 15 & 20 & 25 & 30 & $3-5$ \\
III & 3 & 7 & 15 & 20 & 25 & 30 & $3-5$ \\
\hline
\end{tabular}


Table 5 Suggestion for a regimen for using commercial tanning beds as a dermatologic treatment

\begin{tabular}{|c|c|c|c|c|}
\hline Starting dose & $\begin{array}{l}\text { Frequency } \\
\text { per week }\end{array}$ & $\begin{array}{l}\text { Dosage } \\
\text { increments }\end{array}$ & In case of side effects & Other suggestions \\
\hline $\begin{array}{l}\text { Half the time } \\
\text { recommended by }\end{array}$ & 6-7 times & $15 \mathrm{~s}$ & $\begin{array}{l}\text { Have patients skip the next } \\
\text { treatment or two }\end{array}$ & $\begin{array}{l}\text { Have the patient use the same } \\
\text { tanning bed for every treatment }\end{array}$ \\
\hline $\begin{array}{l}\text { tanning bed attendant, } \\
\text { less if patient is very } \\
\text { fair skinned }\end{array}$ & & & $\begin{array}{l}\text { Stop incrementally increasing } \\
\text { treatment times and revert back } \\
\text { to the last treatment length } \\
\text { that did not cause side effects }\end{array}$ & $\begin{array}{l}\text { Patients should be careful if they } \\
\text { miss consecutive treatments or } \\
\text { if the tanning bed is changed } \\
\text { since they may burn more easily }\end{array}$ \\
\hline
\end{tabular}

(Table 2). The evidence for the use of commercial tanning, with its clear doseresponse effect [18], is as strong as or stronger than for sun exposure, which lacks demonstration of a dose-response effect [59]. Moreover, dosimetry can be better controlled with the use of indoor tanning when compared to exposure to natural sunlight, which can vary greatly based on geographical location, weather conditions, and the time of day and year [59]. The National Psoriasis Foundation [2] recommends natural sunlight as a potential treatment for psoriasis. Considering this, recommending the use of tanning beds as a potential treatment may be just as reasonable.

\section{CONCLUSIONS}

While the use of tanning beds may not be right for every patient, in some patients the benefits of tanning beds as a source of UV therapy for their dermatological disease may be beneficial. Whether physicians recommend commercial tanning bed use or not, patients are likely to try it. In one study, nearly a third of male patients with psoriasis and nearly half of female patients with psoriasis reported having tried tanning as a treatment [15]. Withholding information on how to best use tanning may not be in our patients' best interest. While tanning beds carry the possibility for significant side effects, their benefits and risks should be weighted just as with any treatment or medication. Furthermore, the risks of treatments that would be used as an alternative to tanning beds should also be considered, as many medications, such as methotrexate, carry the risk of severe side effects. Although there are significant risks associated with tanning beds, completely discounting its use may be a disservice to patients who have poor access to in-office and home phototherapy.

\section{ACKNOWLEDGMENTS}

This manuscript was not supported by any grants. The Center for Dermatology Research is supported by an unrestricted educational grant from Galderma Laboratories, L.P. All named authors meet the International Committee of Medical Journal Editors (ICMJE) criteria for authorship for this manuscript, take responsibility for the integrity of the work as a whole, and have given final approval for the version to be published.

Conflict of interest. Dr. Feldman is a speaker for Janssen and Taro. He is a consultant and speaker for Galderma, Stiefel/GlaxoSmithKline, 
Abbott Labs, Leo Pharma Inc. Dr. Feldman has received grants from Galderma, Janssen, Abbott Labs, Amgen, Stiefel/GlaxoSmithKline, Celgene, and Anacor. He is a consultant for Amgen, Baxter, Caremark, Gerson Lehrman Group, Guidepoint Global, Hanall Pharmaceutical Co Ltd, Kikaku, Lilly, Merck \& Co Inc, Merz Pharmaceuticals, Mylan, Novartis Pharmaceuticals, Pfizer Inc, Qurient, Suncare Research, and Xenoport. He is on an advisory board for Pfizer Inc. Dr. Feldman is the founder and holds stock in Causa Research and holds stock and is majority owner in Medical Quality Enhancement Corporation. $\mathrm{He}$ receives royalties from UpToDate and Xlibris. Dr. Radack, Mr. Farhangian, and Ms. Anderson have no conflicts to disclose.

Compliance with ethics guidelines. This article is based on previously conducted studies and does not involve any new studies of human or animal subjects performed by any of the authors.

Open Access. This article is distributed under the terms of the Creative Commons Attribution Noncommercial License which permits any noncommercial use, distribution, and reproduction in any medium, provided the original author(s) and the source are credited.

\section{REFERENCES}

1. Rajpara AN, O'Neill JL, Nolan BV, Yentzer BA, Feldman SR. Review of home phototherapy. Dermatol Online J. 2010;16(12):2.

2. National Psoriasis Foundation. Light Therapy. 2014.

3. U.S.Food and Drug Administration. CFR-Code of Federal Regulations Title 21. 8. 4-1-2012. 2-4-2013.

4. Fleischer $\mathrm{AB}$ Jr, Lee WJ, Adams DP, Zanolli MD. Tanning facility compliance with state and federal regulations in North Carolina: a poor performance. J Am Acad Dermatol. 1993;28(2 Pt 1):212-7.

5. Hornung RL, Magee KH, Lee WJ, Hansen LA, Hsieh YC. Tanning facility use: are we exceeding Food and Drug Administration limits? J Am Acad Dermatol. 2003;49(4):655-61.

6. Oliver H, Ferguson J, Moseley H. Quantitative risk assessment of sunbeds: impact of new high power lamps. Br J Dermatol. 2007;157(2):350-6.

7. Nilsen LT, Aalerud TN, Hannevik M, Veierod MB. UVB and UVA irradiances from indoor tanning devices. Photochem Photobiol Sci. 2011;10(7):1129-36.

8. International Agency for Research on Cancer Working Group-World Health Organization. Exposure to artificial UV radiation and skin cancer. Report No.: 1. 2006.

9. Lazovich D, Vogel RI, Berwick M, Weinstock MA, Anderson KE, Warshaw EM. Indoor tanning and risk of melanoma: a case-control study in a highly exposed population. Cancer Epidemiol Biomarkers Prev. 2010;19(6):1557-68.

10. Cust AE, Armstrong BK, Goumas C, et al. Sunbed use during adolescence and early adulthood is associated with increased risk of early-onset melanoma. Int J Cancer. 2011;128(10):2425-35.

11. Zhang M, Qureshi AA, Geller AC, Frazier L, Hunter DJ, Han J. Use of tanning beds and incidence of skin cancer. J Clin Oncol. 2012;30(14):1588-93.

12. Ferrucci LM, Cartmel B, Molinaro AM, Leffell DJ, Bale AE, Mayne ST. Indoor tanning and risk of early-onset basal cell carcinoma. J Am Acad Dermatol. 2012;67(4):552-62.

13. El GF, Baan R, Straif K, et al. A review of human carcinogens-part D: radiation. Lancet Oncol. 2009;10(8):751-2.

14. Turner RJ, Farr PM, Walshaw D. Many patients with psoriasis use sunbeds. BMJ. 1998;317(7155):412.

15. Fleischer AB Jr, Feldman SR, Rapp SR, Reboussin DM, Exum ML, Clark AR. Alternative therapies commonly used within a population of patients with psoriasis. Cutis. 1996;58(3):216-20.

16. Parrish JA. Treatment of psoriasis with long-wave ultraviolet light. Arch Dermatol. 1977;113(11):1525-8.

17. Young E, van der Leun JC. Treatment of psoriasis with long-wave ultraviolet light. Dermatologica. $1975 ; 150(6): 352-4$. 
18. Das S, Lloyd JJ, Walshaw D, Diffey BL, Farr PM. Response of psoriasis to sunbed treatment: comparison of conventional ultraviolet A lamps with new higher ultraviolet B-emitting lamps. Br J Dermatol. 2002;147(5):966-72.

19. Fleischer AB Jr, Clark AR, Rapp SR, Reboussin DM, Feldman SR. Commercial tanning bed treatment is an effective psoriasis treatment: results from an uncontrolled clinical trial. J Invest Dermatol. 1997;109(2):170-4.

20. Cunliffe WJ, Berth-Jones J, Claudy A, et al. Comparative study of calcipotriol (MC 903) ointment and betamethasone 17-valerate ointment in patients with psoriasis vulgaris. J Am Acad Dermatol. 1992;26(5 Pt 1):736-43.

21. Krutmann J, Czech W, Diepgen T, Niedner R, Kapp A, Schopf E. High-dose UVA1 therapy in the treatment of patients with atopic dermatitis. J Am Acad Dermatol. 1992;26(2 Pt 1):225-30.

22. Turner RJ, Walshaw D, Diffey BL, Farr PM. A controlled study of ultraviolet A sunbed treatment of psoriasis. Br J Dermatol. 2000;143(5):957-63.

23. Lowe NJ, Prystowsky JH, Bourget T, Edelstein J, Nychay S, Armstrong R. Acitretin plus UVB therapy for psoriasis. Comparisons with placebo plus UVB and acitretin alone. J Am Acad Dermatol. 1991;24(4):591-4.

24. Carlin CS, Callis KP, Krueger GG. Efficacy of acitretin and commercial tanning bed therapy for psoriasis. Arch Dermatol. 2003;139(4):436-42.

25. Koek MB, Buskens E, van Weelden H, Steegmans $\mathrm{PH}$, Bruijnzeel-Koomen CA, Sigurdsson V. Home versus outpatient ultraviolet $B$ phototherapy for mild to severe psoriasis: pragmatic multicentre randomised controlled non-inferiority trial (PLUTO study). BMJ. 2009;338:b1542.

26. Hamilton FL, Car J, Lyons C, Car M, Layton A, Majeed A. Laser and other light therapies for the treatment of acne vulgaris: systematic review. Br J Dermatol. 2009;160(6):1273-85.

27. Song BH, Lee $\mathrm{DH}$, Kim BC, et al. Photodynamic therapy using chlorophyll-a in the treatment of acne vulgaris: a randomized, single-blind, split-face study. J Am Acad Dermatol. 2014;71(4):764-71.

28. Liu LH, Fan X, An YX, Zhang J, Wang CM, Yang RY. Randomized trial of three phototherapy methods for the treatment of acne vulgaris in Chinese patients. Photodermatol Photoimmunol Photomed. 2014;30(5):246-53.

29. Boldeman C, Beitner H, Jansson B, Nilsson B, Ullen $\mathrm{H}$. Sunbed use in relation to phenotype, erythema, sunscreen use and skin diseases. A questionnaire survey among Swedish adolescents. Br J Dermatol. 1996;135(5):712-6.

30. Malinowska K, Sysa-Jedrzejowska A, Wozniacka A. UVA1 phototherapy in dermatological treatment. Post Dermatol Alergol. 2011;28(1):53-8.

31. Kowalzick L, Kleinheinz A, Weichenthal M, et al. Low dose versus medium dose UV-A1 treatment in severe atopic eczema. Acta Derm Venereol. 1995;75(1):43-5.

32. Jekler J, Larko O. Phototherapy for atopic dermatitis with ultraviolet A (UVA), low-dose UVB and combined UVA and UVB: two paired-comparison studies. Photodermatol Photoimmunol Photomed. 1991;8(4):151-6.

33. Osmola-Mankowska A, Polanska A, Silny W, Zaba R, Adamski Z, Danczak-Pazdrowska A. Topical tacrolimus vs medium-dose ultraviolet al phototherapy in the treatment of atopic dermatitis-a preliminary study in relation to parameters of the epidermal barrier function and high-frequency ultrasonography. Eur Rev Med Pharmacol Sci. 2014;18(24):3927-34.

34. Jekler J, Larko O. Combined UVA-UVB versus UVB phototherapy for atopic dermatitis: a pairedcomparison study. J Am Acad Dermatol. 1990;22(1):49-53.

35. Heinlin J, Schiffner-Rohe J, Schiffner R, et al. A first prospective randomized controlled trial on the efficacy and safety of synchronous balneophototherapy vs. narrow-band UVB monotherapy for atopic dermatitis. J Eur Acad Dermatol Venereol. 2011;25(7):765-73.

36. Rosen K, Mobacken H, Swanbeck G. Chronic eczematous dermatitis of the hands: a comparison of PUVA and UVB treatment. Acta Derm Venereol. 1987;67(1):48-54.

37. Simons JR, Bohnen IJ, van der Valk PG. A left-right comparison of UVB phototherapy and topical photochemotherapy in bilateral chronic hand dermatitis after 6 weeks' treatment. Clin Exp Dermatol. 1997;22(1):7-10.

38. van Coevorden AM, Kamphof WG, van Sonderen E, Bruynzeel DP, Coenraads PJ. Comparison of oral psoralen-UV-A with a portable tanning unit at home vs hospital-administered bath psoralen-UVA in patients with chronic hand eczema: an openlabel randomized controlled trial of efficacy. Arch Dermatol. 2004;140(12):1463-6.

39. Abdallat SA, Alqaqaa AS, Obaidat NA, Alnueimi RF. Efficacy and side effects of narrowband-UVB in early stage cutaneous T-cell lymphoma in jordanian patients. ISRN Dermatol. 2014;2014:951821. 
40. Olek-Hrab K, Silny W, Danczak-Pazdrowska A, Osmola-Mankowska A, Sadowska PA, Polanska A, et al. Ultraviolet al phototherapy for mycosis fungoides. Clin Exp Dermatol. 2013;38(2):126-30.

41. Hamzavi IH, Lim HW, Syed ZU. Ultraviolet-based therapy for vitiligo: what's new? Indian J Dermatol Venereol Leprol. 2012;78(1):42-8.

42. Majid I. Efficacy of targeted narrowband ultraviolet $\mathrm{B}$ therapy in vitiligo. Indian $\mathrm{J}$ Dermatol. 2014;59(5):485-9.

43. Shan X, Wang C, Tian H, Yang B, Zhang F. Narrowband ultraviolet $\mathrm{B}$ home phototherapy in vitiligo. Indian J Dermatol Venereol Leprol. 2014;80(4):336-8.

44. Baldo A, Lodi G, Di CP, Monfrecola G. Vitiligo, NBUVB and tacrolimus: our experience in Naples. G Ital Dermatol Venereol. 2014;149(1):123-30.

45. El-Mofty M, Mostafa W, Youssef R, et al. BB-UVA vs. NB-UVB in the treatment of vitiligo: a randomized controlled clinical study (single blinded). Photodermatol Photoimmunol Photomed. 2013;29(5):239-46.

46. Krutmann J, Honigsmann $H$, Elmets CA. Dermatological phototherapy and photodiagnostic methods. Springer; 2009.

47. Krutmann J, Morita A. Mechanisms of ultraviolet (UV) B and UVA phototherapy. J Investig Dermatol Symp Proc. 1999;4(1):70-2.

48. Kumakiri M, Hashimoto K, Willis I. Biological changes of human cutaneous nerves caused by ultraviolet irradiation: an ultrastructural study. Br J Dermatol. 1978;99(1):65-75.

49. Gilchrest BA, Rowe JW, Brown RS, Steinman TI, Arndt KA. Relief of uremic pruritus with ultraviolet phototherapy. N Engl J Med. 1977;297(3):136-8.

50. Seckin D, Demircay Z, Akin O. Generalized pruritus treated with narrowband UVB. Int J Dermatol. 2007;46(4):367-70.

51. Wang TJ, Lan LC, Lu CS, et al. Efficacy of narrowband ultraviolet phototherapy on renal pruritus. J Clin Nurs. 2014;23(11-12):1593-602.

52. Blachley JD, Blankenship DM, Menter A, Parker TF III, Knochel JP. Uremic pruritus: skin divalent ion content and response to ultraviolet phototherapy. Am J Kidney Dis. 1985;5(5):237-41.

53. Szepietowski JC, Morita A, Tsuji T. Ultraviolet B induces mast cell apoptosis: a hypothetical mechanism of ultraviolet B treatment for uraemic pruritus. Med Hypotheses. 2002;58(2):167-70.
54. Gilchrest BA. Ultraviolet phototherapy of uremic pruritus. Int J Dermatol. 1979;18(9):741-8.

55. Pardo RJ, Bogaert MA, Penneys NS, Byrne GE Jr, Ruiz P. UVB phototherapy of the pruritic papular eruption of the acquired immunodeficiency syndrome. J Am Acad Dermatol. 1992;26(3 Pt 2):423-8.

56. Gorin I, Lessana-Leibowitch M, Fortier P, Leibowitch J, Escande JP. Successful treatment of the pruritus of human immunodeficiency virus infection and acquired immunodeficiency syndrome with psoralens plus ultraviolet A therapy. J Am Acad Dermatol. 1989;20(3):511-3.

57. Rivard J, Lim HW. Ultraviolet phototherapy for pruritus. Dermatol Ther. 2005;18(4):344-54.

58. Akaraphanth R, Lim HW. HIV, UV and immunosuppression. Photodermatol Photoimmunol Photomed. 1999;15(1):28-31.

59. Nilsen LT, Soyland E, Krogstad AL. Estimated ultraviolet doses to psoriasis patients during climate therapy. Photodermatol Photoimmunol Photomed. 2009;25(4):202-8.

60. Xiang Y, Liu G, Yang L, Zhong JL. UVA-induced protection of skin through the induction of heme oxygenase-1. Biosci Trends. 2011;5(6):239-44.

61. Rivers JK, Norris PG, Murphy GM, et al. UVA sunbeds: tanning, photoprotection, acute adverse effects and immunological changes. Br J Dermatol. 1989;120(6):767-77.

62. Aubin F. Mechanisms involved in ultraviolet lightinduced immunosuppression. Eur J Dermatol. 2003;13(6):515-23.

63. Stege H, Roza L, Vink AA, et al. Enzyme plus light therapy to repair DNA damage in ultraviolet-Birradiated human skin. Proc Natl Acad Sci. 2000;97(4):1790-5.

64. Seiffert K, Granstein RD. Neuropeptides and neuroendocrine hormones in ultraviolet radiationinduced immunosuppression. Methods. 2002;28(1):97-103.

65. Fisher DE, James WD. Indoor tanning-science, behavior, and policy. $\mathrm{N}$ Engl J Med. 2010;363(10):901-3.

66. Marks DI, Fox RM. Mechanisms of photochemotherapy-induced apoptotic cell death in lymphoid cells. Biochem Cell Biol. 1991;69(10-11):754-60.

67. Gold MH, Rao J, Goldman MP, et al. A multicenter clinical evaluation of the treatment of mild to 
moderate inflammatory acne vulgaris of the face with visible blue light in comparison to topical $1 \%$ clindamycin antibiotic solution. J Drugs Dermatol. 2005;4(1):64-70.

68. Papageorgiou P, Katsambas A, Chu A. Phototherapy with blue $(415 \mathrm{~nm})$ and red $(660 \mathrm{~nm})$ light in the treatment of acne vulgaris. $\mathrm{Br} \mathrm{J}$ Dermatol. 2000;142(5):973-8.

69. Hofer A, Cerroni L, Kerl H, Wolf P. Narrowband (311-nm) UV-B therapy for small plaque parapsoriasis and early-stage mycosis fungoides. Arch Dermatol. 1999;135(11):1377-80.

70. Bhatnagar A, Kanwar AJ, Parsad D, De D. Comparison of systemic PUVA and NB-UVB in the treatment of vitiligo: an open prospective study. J Eur Acad Dermatol Venereol. 2007;21(5):638-42.
71. Yones SS, Palmer RA, Garibaldinos TM, Hawk JL. Randomized double-blind trial of treatment of vitiligo: efficacy of psoralen-UV-A therapy vs Narrowband-UV-B therapy. Arch Dermatol. 2007;143(5):578-84.

72. Casacci M, Thomas P, Pacifico A, Bonnevalle A, Paro VA, Leone G. Comparison between 308-nm monochromatic excimer light and narrowband UVB phototherapy $(311-313 \mathrm{~nm})$ in the treatment of vitiligo-a multicentre controlled study. J Eur Acad Dermatol Venereol. 2007;21(7):956-63.

73. Matsumura Y, Ananthaswamy HN. Toxic effects of ultraviolet radiation on the skin. Toxicol Appl Pharmacol. 2004;195(3):298-308. 